\title{
A Critical Review of Alternative Erection Methods for Overhead Line Towers
}

\author{
Mr. Bertie Jacobs ${ }^{1}$, Dr. Dawood A Desai ${ }^{2}$ and Dr. Lukas du Plessis ${ }^{3}$ \\ ${ }^{1}$ Doctoral Student, Dept. of Mechanical \& Automation Eng, Tshwane University of Technology, South Africa. \\ ${ }^{2}$ Section Head and Senior Lecturer, Dept. of Mechanical \& Automation Eng, Tshwane University of Technology, South Africa. \\ ${ }^{3}$ Senior Lecturer, Dept. of Mechanical \& Aeronautical Eng, University of Pretoria, South Arica.
}

\begin{abstract}
The construction of overhead power lines in the EHV (Extra High Voltage) category is a costly exercise. For the erection of the towers that supports the conductors, mobile cranes have become the dominant piece of equipment to erect these towers. Although convenient and relatively quick, these mobile cranes do come at a considerable cost and hence, alternative erection methods will be economically beneficial. This paper takes a critical review of alternative options to erect overhead power line towers thereby eliminating mobile cranes. The work presented here is part of a larger study to develop a numerical safety tool for the safe erection of guyed V-towers without cranes. It proposes the use of novel methods like air cushions and a degree of automation to lift these guyed V-towers autonomously. This paper deals with the first part of the study and analyses the different lifting configurations using gin poles and winches and selects the most suitable method to achieve this.
\end{abstract}

Keywords: Gin poles, guyed V-tower, mobile cranes, overhead power lines, winches.

\section{INTRODUCTION}

In South Africa, most of the $31000 \mathrm{~km}$ overhead power lines that are built in the $132 \mathrm{kV}$ up to $765 \mathrm{kV}$ range consist of lattice steel towers which are used to support the conductor bundles [1]. Contractors responsible for constructing overhead lines, in this voltage range, normally use mobile cranes to erect the towers that support the conductors. Crane sizes vary from 70 ton capacity up to 250 ton depending on the line voltage and subsequent tower size (mass and height). Often, due to the height of the towers, a bigger capacity crane is required simply to achieve the required reach (height) without using the crane to its limit in terms of lifting capacity. Frequently, unfavorable terrain conditions (like semi desert and loose sand) are encountered that hinder the mobility and operation of the crane. In these conditions additional equipment or construction techniques is required that adds to the construction cost. Some of the additional equipment and methods utilized includes helicopter construction and gin poles [2]. Both methods have disadvantages and this paper investigates the first phase of an alternative lifting proposal that will eliminate mobile cranes and be more economical.

\section{AN ALTERNATIVE METHOD}

By using gin poles and hoisting winches in a suitable configuration and layout, the alternative basic methodology can be seen in Fig. 1 and 2. The tower selected for this study is a guyed V-suspension tower type 520B often used on 400 $\mathrm{kV}$ lines in South Africa.

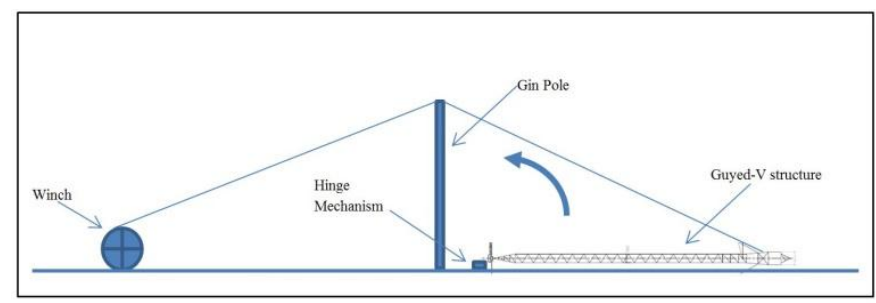

Fig. 1. Side view of alternative lifting concept prior to lift.

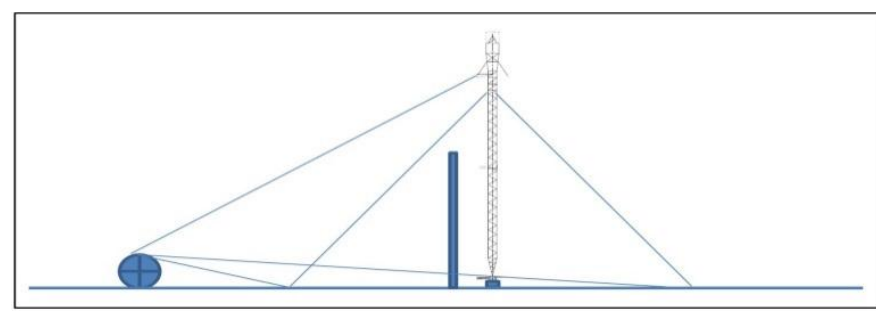

Fig. 2. Tower in upright position after lift.

The concept entails complete assembly of the tower on the ground as close as possible to its foundation and in-line with the running direction of the overhead line. A hinge mechanism will be positioned with jacks over the tower foundation and the tower bottom will in turn be attached to the hinge mechanism. The height and position of gin pole as well as position of winches need to be determined and positioned in accordance with a numerical "safety tool" that will determine the safe positioning and size of equipment required for the operation. Any temporary anchor points are then positioned. Furthermore, all the lifting ropes are attached and the necessary sensors like load cells, angle inclinometers and accelerometers are connected to a control system. Lifting can now commence by means of the main winch while secondary winches will ensure stability of the tower during the lifting process under command of the control system. Due to the inherent instability of a guyed V- 
type tower a number of lifting and stabilizing ropes will be required and manual control of such ropes when using winches may be difficult and unsafe by a human operator. Hence, the control system will use input data like tensions in the different ropes, rate of lift and angle of tilt and will control the winches to maintain a stable and safe lift. This part of the lifting process will happen autonomously without any human input except to keep a watchful eye to interrupt or stop the lifting process in case of emergency. Once the tower is upright, workers will use jacks to lower the tower onto its foundation, the permanent guy ropes will then be attached to its anchors and the hinge mechanism removed. Workers can then disconnect all other construction ropes and equipment and move on to the next tower.

\section{STUDY OF THE BASIC LIFTING METHOD}

Due to the number of variations possible using gin poles and winches, four different lifting configurations and two variations yielding a total of six options was evaluated. As a first step the boundary conditions of the concept required to be determined in order to ensure the tower is not damaged and to get an idea of loads and forces required for the lifting process. Structure analysis software (PLSTower) is used to model the 520B guyed V-tower and position of gin pole and winches that is simulated. Fig. 3 shows the basic lifting method model. In modelling the $520 \mathrm{~B}$ tower the following key parameters is used;
- Tower height
$=39.65 \mathrm{~m}$
- Conductor Attachment Height (CAH)
$=33.0 \mathrm{~m}$
- Tower mass $=7960 \mathrm{~kg}$

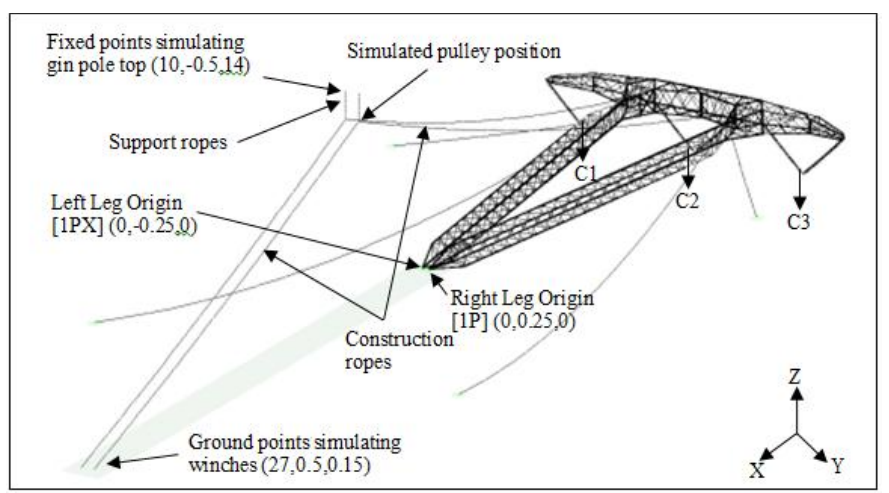

Fig. 3. Modelling of the basic lifting concept to determine boundary conditions.

One of the key parameters that are required is the minimum height of gin pole required to lift the complete tower with hardware and running blocks and not over stressing any of the tower members. It can be realized that with the basic lifting concept as indicated in Fig. 3 the lower the gin pole height the higher the load become in the tower legs since the legs bear against a hinge mechanism that will be used to lower the tower onto its foundation once in the upright position.
Detail study of the type 520B tower shows that by moving the attachment point of the construction rope on the tower to a point lower down the legs compared to the normal guy rope attachment position which is used for construction purposes, no overstressing of any member occurred for the following boundary conditions. With reference to Fig. 4;

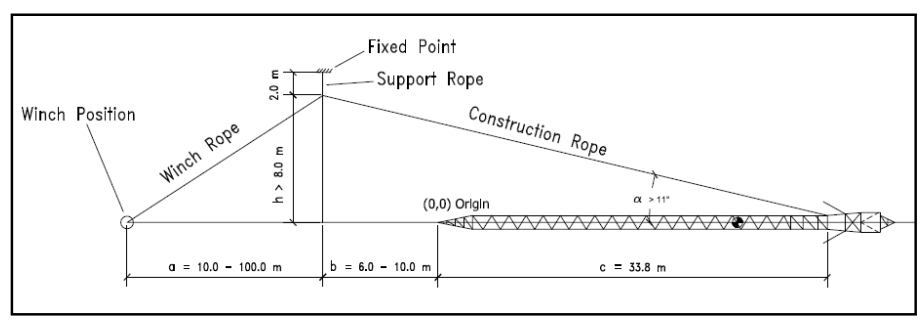

Fig. 4. Key boundaries conditons for using gin pole to lift type 520B guyed V-tower.

- The angle " $\alpha$ " with a value of $11^{\circ}$ between construction rope and tower body is selected as the minimum.

- The gin pole pulley height limits are selected as $8 \mathrm{~m}$ and $16 \mathrm{~m}$ such that $8 \mathrm{~m} \leq \mathrm{h} \leq 16 \mathrm{~m}$. The minimum limit of $8 \mathrm{~m}$ was set to prevent an angle $\alpha$ becoming smaller than $11^{\circ}$, and the maximum limit of $16 \mathrm{~m}$ was set to double the minimum limit.

- The distance "a" between gin pole base and the winch is at its minimum $10 \mathrm{~m}$ and at its maximum $100 \mathrm{~m}$. The distance of $10 \mathrm{~m}$ is based on the minimum gin pole attachment point height of $8 \mathrm{~m}$ and applying a safety zone factor of 1.2. Positioning a winch more than $100 \mathrm{~m}$ away is considered impractical due to the excessive lengths of construction ropes that such positioning will require.

- The minimum distance "b" between tower foundation and gin pole base is $6 \mathrm{~m}$ while the maximum distance is limited to $10 \mathrm{~m}$. These values are based on practical experience from site conditions where a reasonable gap is necessary for vehicles and workers to safely move and work.

- The maximum offset of the winch from the centre line is such that the plan view projected angle between winch's construction rope and the centre line is $<5^{\circ}$.

\section{EXISTING GIN POLE DESIGNS}

A gin pole can be designed in various forms to cater for specific needs. In the overhead line construction industry, gin poles normally have a triangular or square cross-section and are made either from an aluminum alloy tubular material or steel, which is welded to form separate sections [3]-[5]. These sections are then assembled on site where the required height determines the number of sections in the assembly. The lifting capacity of the gin pole is determined by its length and tilt angle. The gin pole has a swivel head and swivel base and can be used in an upright position or slightly tilted angle in the order of $20^{\circ}$ to lift light loads. It is held stable 
and in position by a number of ropes attached to the top part of the gin pole. Normally, small winches in combination with pulley blocks are used to hoist the load into position although for lighter loads hand hoisting can be used as well [6].

Seeing that the standard range of gin poles that could be sourced all fall short for the application under consideration, a new gin pole design is proposed here. Since contractors in South Africa are familiar with steel angle sections which are bolted together to for example assemble a tower on site, a decision was made to use Grade S355JR steel angle sections [7] which will be bolted together for the design of any gin pole(s) used in this study. This makes manufacturing relatively simple as no special material, welding or other precautions is required, whilst at the same time the construction industry is familiar with this material and assembly thereof.

\section{CRITICAL EVALUATION OF DIFFERENT GIN POLE LIFTING CONFIGURATIONS}

There are many different configurations in which gin pole(s) can be used to perform a certain task and this study focuses on four possible lifting configurations for lifting the 520B guyed V-tower with a further two variations on two of the lifting configurations, bringing the total to six that are investigated and compared.

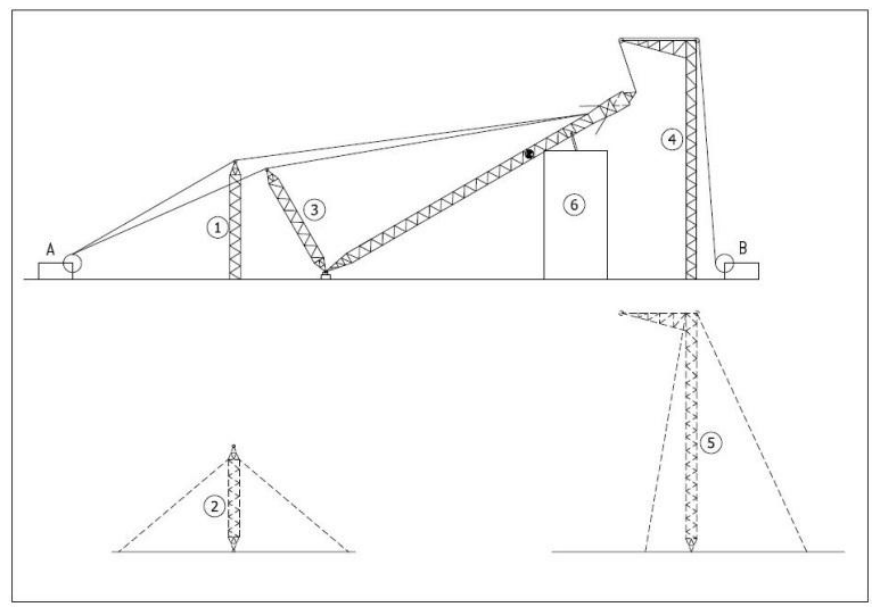

Fig. 5. Different gin pole lifting configurations.

Fig. 5 shows the six different lifting configurations that are investigated. The different lifting configurations are all superimposed showing the 520B tower partly lifted. The dotted inset at the bottom shows the alternative configurations using a guyed gin pole instead of a self-supporting type for options 1 and 4 . A brief description of the different options is given below with reference to Fig. 5 .

\section{V.I. Option 1}

The first option is to have the gin pole standing separately from the tower. This configuration represents the basic configuration where the gin pole is self-supporting and need to be anchored to some means of temporary foundation to cater for the compression and uplift forces expected at its base.

\section{V.II. Option 2}

This is a variation of option 1 in that the gin pole has a tapered bottom and will be supported additionally with guy ropes to ensure stability.

\section{V.III. Option 3}

In this configuration the gin pole has its base located at the same hinge point as that of the tower, with a fixed rope length between the gin pole and tower. Guy ropes will be used for stabilization of the gin pole as it rotates relative to the ground during the lifting of the tower.

\section{V.IV. Option 4}

Two winches are required for option 4 where the gin pole is located on the opposite end of the tower and where it is selfsupported, but needs to be anchored to a temporary foundation to cater for the compression and uplift forces expected at its base. Depending on the allowable distance between winch $\mathrm{A}$ and the tower foundation, a secondary gin pole can be employed to shorten this distance. In this configuration the gin pole is used to lift the tower to a sufficient height so that angle $\alpha>11^{\circ}$ in order for the main winch to complete the lifting process.

\section{V.V. Option 5}

Option 5 is a variation of option 4 except that the gin pole is not self-supported due to a tapered base and will require guy ropes to maintain stability.

\section{V.VI. Option 6}

An air cushion is used to raise the tower to a sufficient height to satisfy the requirements of angle $\alpha>11^{\circ}$. By using an air cushion which is filled with air blown in under low pressure (similar to inflatable jumping castles) the process will eliminate gin pole(s) except, similar to options 4 and 5 , if the distance between the winch and tower foundation need to be reduced in which case a secondary gin pole can be used.

\section{THEORETICAL COMPARISON OF LIFTING CONFIGURATIONS}

Since this study proposes six different lifting configurations a theoretical comparison is required to perform a final concept selection, which will be used in a subsequent study to determine the loads on the hinge mechanism that will support the tower as it rotates into its upright position.

Observations and anecdotal evidence suggest that the criteria presented in Table 1 can be applied to perform the comparison which will be presented in a decision matrix. 
Table 1. Criteria For Decision Matrix

\begin{tabular}{|c|c|c|c|}
\hline Parameter & Value & Points & Weight (\%) \\
\hline $\begin{array}{l}\text { Compression } \\
\text { FoundationLoads }\end{array}$ & $\begin{array}{c}\text { High }>1000 \mathrm{kN} \\
500 \mathrm{kN}<\mathrm{Med}<1000 \mathrm{kN} \\
\text { Low }<500 \mathrm{kN}\end{array}$ & $\begin{array}{l}1 \\
2 \\
3\end{array}$ & 12 \\
\hline $\begin{array}{l}\text { Uplift Foundation } \\
\text { Loads }\end{array}$ & $\begin{array}{c}\text { High }>1000 \mathrm{kN} \\
500 \mathrm{kN}<\mathrm{Med}<1000 \mathrm{kN} \\
\text { Low }<500 \mathrm{kN}\end{array}$ & $\begin{array}{l}1 \\
2 \\
3\end{array}$ & 18 \\
\hline $\begin{array}{l}\text { No of guy ropes for } \\
\text { gin pole }\end{array}$ & $\begin{array}{c}>4 \text { guy ropes } \\
2<\text { guy ropes } \leq 4 \\
\leq 2 \text { guy ropes }\end{array}$ & $\begin{array}{l}1 \\
2 \\
3\end{array}$ & 10 \\
\hline No of main winches & $\begin{array}{l}3 \\
2 \\
1\end{array}$ & $\begin{array}{l}1 \\
2 \\
3\end{array}$ & 25 \\
\hline No of gin poles & $\begin{array}{l}2 \\
1\end{array}$ & $\begin{array}{l}1 \\
2\end{array}$ & 10 \\
\hline $\begin{array}{l}\text { Total mass of gin } \\
\text { pole(s) }\end{array}$ & $\begin{array}{c}\text { Mass }>3 \text { tons } \\
2<\text { mass } \leq 3 \text { tons } \\
\text { Mass } \leq 2 \text { tons }\end{array}$ & $\begin{array}{l}1 \\
2 \\
3\end{array}$ & 15 \\
\hline $\begin{array}{l}\text { No of additional } \\
\text { anchor points }\end{array}$ & $\begin{array}{l}>4 \\
\leq 4\end{array}$ & $\begin{array}{l}1 \\
2\end{array}$ & 10 \\
\hline & & & 100 \\
\hline
\end{tabular}

\section{VI.I. Discussion of Criteria Parameters}

\section{VI.I.I Foundation Loads}

The smaller the foundation loads the better. Preparing and installation of foundations are a time consuming and costly operation. Compression loads (into the ground) can be more easily catered for compared to uplift (out of the ground) type loads. For compression loads, devices or designs that distribute the load over an area at ground level taking into consideration the soil type, can more easily be accomplished compared to uplift load where normally some digging need to be done in order to install an anchor system. Therefore, the uplift foundation loads of both the gin pole and associated anchors which may be required is more important than compression foundation loads and subsequently carry a bigger weight factor.

\section{VI.I.II Number Of Guy Ropes}

Traditionally gin poles require a number of guy ropes to stabilize the mast or pole. The installation of such stabilizing ropes is a time consuming operation as each rope is in tension under normal operating conditions and anchors need to be devised for each one. Therefore the less guy ropes to deal with the quicker the installation can be done.

\section{VI.I.III Number of Winches}

Winches can range in size and capacity from $5 \mathrm{kN}$ up to 180 $\mathrm{kN}$. Some can pull more than one rope at a time depending on model, while others have built-in and adjustable tension regulators that can control both speed and tension automatically. In general, winches are costly and require additional anchor points to ensure safe operation.

\section{VI.I.IV Mass of Gin Pole}

Since a gin pole is traditionally used to lift relative small loads it requires a lot of repositioning in order to pick up tower members and position them in the correct place. Therefore, the lighter the gin pole the easier it is to maneuver and to transport. The same is true for the gin pole that is designed in this study.

\section{VI.I.VNumber of Additional Anchor Points}

Concrete blocks weighing approximately 1 ton each are the most basic anchor point contractors use on site. For lightweight applications they can be used as a single block, preferably buried halfway into the ground, with a rope or steel cable attached to it. When more weight is required, the blocks are stacked into a steel frame which in turn is buried into the ground. The preparation of these anchor points is a time consuming job.

\section{DECISION MATRIX}

Using the data obtained from the PLS Tower models and the decision criteria as per Table 1, the following decision matrix was compiled. Each option has two rows where the data values are represented in the first row (grey shaded cells) and the corresponding score in the second row. The total score (column $\mathrm{H}$ ) is calculated by also considering the different weight factors as follows;

$$
\sum_{\text {Col } G}^{\operatorname{Col} A} \text { Score value } \times\left(\frac{\text { Weight factor }}{100}\right)
$$

where A to $\mathrm{G}$ is score values in corresponding columns from Table 1 and weight factor from last column in same table.

Table 2. Decision Matrix Table

\begin{tabular}{|c|c|c|c|c|c|c|c|c|c|c|}
\hline $\begin{array}{c}\text { Option } \\
\text { No }\end{array}$ & & $\begin{array}{c}A \\
\text { Vert Found } \\
\text { [-Comp] } \\
(\mathrm{kN})\end{array}$ & $\begin{array}{c}\text { B } \\
\text { Vert } \\
\text { Found } \\
{\left[+\mathrm{U}_{\mathrm{p}}\right]} \\
(\mathrm{kN})\end{array}$ & $\begin{array}{l}\text { C } \\
\text { No } \\
\text { of } \\
\text { Gu } \\
\text { ys }\end{array}$ & $\begin{array}{c}\text { D } \\
\text { No of } \\
\text { main } \\
\text { Winches }\end{array}$ & $\begin{array}{c}E \\
\text { No of } \\
\text { Gin } \\
\text { Poles }\end{array}$ & $\begin{array}{c}\mathbf{F} \\
\text { Mass of } \\
\text { Gin } \\
\text { Poles } \\
\text { (tons) }\end{array}$ & $\begin{array}{c}\mathrm{G} \\
\text { No of } \\
\text { Ancho } \\
\text { rs }\end{array}$ & $\begin{array}{c}\text { H } \\
\text { Total } \\
\text { Score }\end{array}$ & $\%$ \\
\hline & $\begin{array}{l}\text { Weight } \\
\text { factor } \\
(\%)\end{array}$ & 12 & 18 & 10 & 25 & 10 & 15 & 10 & 100 & \\
\hline 1 & $\begin{array}{l}\text { Data } \\
\text { Val }\end{array}$ & -1965.5 & 1594.7 & 0 & 2 & 1 & 2.839 & 0 & & \\
\hline & Score & 1 & 1 & 3 & 2 & 2 & 2 & 2 & 1.8 & 64.3 \\
\hline 2 & $\begin{array}{c}\text { Data } \\
\text { Val }\end{array}$ & -1468.4 & 392.5 & 4 & 2 & 1 & 0.969 & 4 & & \\
\hline & Score & 1 & 3 & 2 & 2 & 2 & 3 & 2 & 2.21 & 78.9 \\
\hline 3 & $\begin{array}{c}\text { Data } \\
\text { Val }\end{array}$ & -1042.6 & 80.0 & 2 & 1 & 1 & 1.535 & 2 & & \\
\hline & Score & 1 & 3 & 3 & 3 & 2 & 3 & 2 & 2.56 & 91.4 \\
\hline 4 & $\begin{array}{c}\text { Data } \\
\text { Val }\end{array}$ & -149.4 & 3.72 & 0 & 3 & 1 & $2.584^{\mathrm{a}}$ & $0^{b}$ & & \\
\hline & Score & 3 & 3 & 3 & 1 & 2 & 2 & 2 & 2.15 & 76.8 \\
\hline 5 & $\begin{array}{c}\text { Data } \\
\text { Val }\end{array}$ & -303.9 & 30.2 & 4 & 3 & 1 & $2.473^{\mathrm{a}}$ & $4^{b}$ & & \\
\hline & Score & 3 & 3 & 2 & 1 & 2 & 2 & 2 & 2.05 & 73.2 \\
\hline 6 & $\begin{array}{c}\text { Data } \\
\text { Val }\end{array}$ & N/A & N/A & N/A & 3 & 2 & N/A & $0^{b}$ & & \\
\hline & Score & 3 & 3 & 3 & 2 & 2 & 3 & 2 & 2.55 & 91.1 \\
\hline
\end{tabular}

Notes: a-only one gin pole is considered here. b-secondary gin pole is not considered here. 


\section{DISCUSSION OF RESULTS}

The alternative lifting system proposed here was designed to lift the complete guyed-V suspension tower type 520B completely "dressed" [8] with insulators and running blocks connected, which will enable contractors to start with the stringing process directly after the tower is erected and secured.

From the decision matrix it can be seen that option three ranks the highest followed by option six and then option two. For options four and five the best case scenario of using only one gin pole was used in the evaluation. If a second gin pole is employed in the comparison it would increase the mass of the gin poles as well as number of guy ropes and would therefore lower its score further.

Since mobility and weight of the alternative lifting system is critical for the success of the concept, the air cushion proposal deserves further investigation because no gin pole will be required to complete the lifting process.

\section{CONCLUSIONS}

There is a clear and urgent need to find other more economical methods to erect transmission towers. The use of gin poles and winches has to date not been implemented for this application and is investigated here for lifting a type 520B guyed V- tower. A comparison of six different lifting configurations using gin poles and winches is done by means of a scientific methodology that has been formulated. The same limitations, criteria and assumptions are applied to all configurations and hence a fair comparison is made leading to a clear distinction between two feasible and four infeasible lifting configurations.

The most suitable gin pole and winch lifting configuration is represented in Fig. 5 option 3, where the gin pole is attached to the tower base. An unconventional lifting configuration where an air cushion is applied instead of a gin pole is also investigated. This latter lifting configuration compares very favorable with the most suitable gin pole and winch lifting configuration. Subsequent work will be conducted to further compare these two options in more detail.

The study thus far indicated that the numerical safety tool will provide much needed guidance and assistance for low skilled construction workers which will ensure correct placement and size of lifting equipment required.

The alternative lifting concept can be scaled up or down in order to for example lift similar guyed- $\mathrm{V}$ suspension towers type 702B used on $765 \mathrm{kV}$ overhead lines in South Africa. Similarly for lower voltage lines and where access to machinery like mobile cranes is difficult and expensive, this concept can offer a solution.

\section{REFERENCES}

[1] Eskom Holdings Corporate Plan, pp 179, 2016.

[2] Stevens D, "Review of Alternative Construction Methods for Transmission Towers", (Report). University of Cantebury, Feb.2014.

[3] OMAC, "HV Transmission Line Stringing, Machines and Equipment", pp. 111.

[4] TESMEC S.p.A, "Tesmec Stringing Equipment", Nov. 2004, pp. 96-97.

[5] ZECK TSE, "Zeck Tension Stringing Equipment", 2017, pp. 3-4.

[6] F. Kiessling, P. Nefzger, J.F. Nolasco, U. Kaintzyk, "Overhead Power Lines - Planning, Design, Construction". New York: Springer, 2003, pp. 648-652.

[7] The Southern Africa Institute of Steel Construction, "Southern African Steel Construction Handbook", 7th ed., 2010, pp. 2.3-2.4.

[8] B. Badenhortst, P. Marais, "The Planning, Design and Construction of Overhead Power Lines", Johannesburg: Crown Publications cc, 2005, pp 677-722. 